\title{
THE FRAMING EFFECT AMONG EXECUTIVE OFFICERS AND BOARD MEMBERS
}

Received on: 27/02/2015

Approved on: 31/03/2017

Roque Alberto Zin ${ }^{1}$

Paulo Renato Soares Terra²

\begin{abstract}
The objective of this study is to investigate the framing effect in the Brazilian corporate environment. Thus, this paper focuses on loss aversion related to different groups within organizations. Board members and executive officers are at first qualified, well prepared, and hold positions in which they are frequently called upon to decide, advise, or evaluate critical decisions. Interviews were held with executives, members of the Boards of Directors (henceforth simply board members) and Audit Committee members (henceforth AC members) from publicly traded companies listed on the São Paulo Stock Exchange (BM\&FBovespa). The results suggest that the framing effect occurs differently among $A C$ members and the other respondents. With respect to the loss, $30.28 \%$ of the board members opt to spend $8 \%$ or more, however only $22.02 \%$ would do the same to avoid reducing a profit, a drop of 8.26 percentage points. This research contributes towards the field of behavioral finance by demonstrating how the framing effect manifests even among a group of experts. The main findings of this study suggest the presence of the framing effect even among qualified professionals.
\end{abstract}

Keywords: Prospect theory, framing effect, board of directors, executives

\footnotetext{
1 Graduation at Business Administration from University of Caxias do Sul (1985), and a Ph. D. degree in Financial from Federal University of Rio Grande do Sul (2009). Caxias do Sul - RS. Brasil

E-mail: roque@majorem.com.br

2 Graduation at Business Administration, MSc in business Administration from Federal University of Rio Grande do Sul (1985) and a Ph. D. degree in Financial from Mcgill University, McGill, Canadá. São Paulo - SP. Brasil.

E-mail: prsterra@ea.ufrgs.br
}

Rev. AdM. UfSM, SANTA MARIA, v. 11, NUMBeR 3, P. 757-771, 2018 


\section{INTRODUCTION}

According to Tversky and Kahneman (1981) the framing effect reveals that two problems with equal results can lead to different decisions. The changes result from changes in the formulation of the problem. As an example, the authors state that the term "loss" has a more negative connotation than "costs". People generally deal more easily with the "cost" for an unrewarded bet but are reluctant to admit they lost a bet. May this effect also arise in the corporate environment, or are people who make decisions constantly less affected by these influences?

The financial literature identifies the agency conflict, due to diverging interests between shareholders and corporate executives. Decisions can be influenced by the share between risks and rewards of the borrowers. In public companies the board members represent the shareholders, while the executives are the agents responsible for the daily decisions of the company management. May the difference in roles and responsibilities between executives and shareholders reveal differences in the framing effect or do executives and directors make rational decisions?

The aim of this study was to determine whether the frame effect manifests itself in a similar way between managers and board members of companies, as well as if its effects on decisions follow the same trend, no matter the position held in the organizational structure.

Financial theory is grounded on the assumption that people's behavior is rational and predictable. Their decisions regarding finances, such as whether or not to make investment, are made in order to maximize their wealth, or the wealth of shareholders in the case of managers. According to Copeland, Weston and Shastri (2005), an optimal investment decision is one that maximizes the expected satisfaction (expected utility) by producing gains in excess of expenditure made over the course of the decision-maker's planning.

Berle and Means (1932) are the first authors to study corporate governance and the effects of separation between ownership and control on managers' performance. Among the potential costs, they point out that the equity dilution strengthens the power of managers leading them to act in their own benefit at the expense of the interests of shareholders. More recently, Garvey and Swan (1994, p. 143) stated "The separation of share ownership and firm control highlighted by Berle and Means in the early 1930s is real. Moreover, it is believed that there are substantially greater departures from shareholder wealth-maximization than it is suggested by the costs of risk-aversion and monitoring stressed in the traditional principal-agent models." In these authors' opinion, the choice of governance mechanisms is complex. Thus, more empirical tests to assess the effectiveness of alternative governance mechanisms are welcome. Ideally, these tests should focus on individual elements and limited comparisons. Therefore, in this study, the focus is on a single phenomenon of behavioral finance and a specific group of officers involved in the management of organizations.

On the other hand, La Porta et al (1998) found that the disperse ownership proposed by Berle and Means (1932) is an exception. Around the world, most organizations have an individual or a family as the major shareholder and conflicts may arise between them and the minority shareholders (the principal-principal problem, Peng and Sauerwald, 2013). In the same train of thought, Ross, Westerfield and Jaffe (2010) suggested that the theory and the available evidence are consistent with the notion that ultimate control is performed by the shareholders and maximization of shareholding value is often achieved. That is due to several control mechanisms that constrain managers to act according to the interests of shareholders. Nevertheless, there are instances in which companies are managed according to the goals of the managers at the expense of shareholders. 
In some cases, behavior is seen to be influenced by emotional and cognitive issues and consequently decisions may be inconsistent with the financial theories. This junction between psychology and economics is the area of interest known as behavioral finance, which takes an alternative view of the behavior of individuals and human rationality in relation to investment decisions.

According to Tversky and Kahneman (1974) heuristics and biases can lead to judgement mistakes. In the decision-making process, the complexity of a problem tends to be reduced in order to simplify the solution. People use intuitive judgments and subjective probabilities in their assessments, which lead them to make the wrong decisions.

This research contributes towards the field of behavioral finance by demonstrating how the framing effect manifests among a group of experts. According to Novemsky and Kahneman (2005) "it would be interesting to test the differences in the functioning of our propositions across different segments". Thus, this paper focuses on loss aversion related to different groups within organizations. Board members and executive officers are at first qualified, well prepared, and hold positions in which they are frequently called upon to decide, advise, or evaluate critical decisions. For this purpose, interviews were held with executives, members of the Boards of Directors (henceforth simply board members) and Audit Committee ${ }^{1}$ members (henceforth AC members) from publicly traded companies listed on the São Paulo Stock Exchange (BM\&FBovespa). The results revealed the opinions of each group of respondents, showed how the wording of the questions changed the answers given, and that the decisions do not always seek to maximize the wealth of the company or of the shareholder.

The structure of the paper is as follows: first there is an outline of Prospect Theory and its evolution with respect to its application in the corporate environment, focusing primarily on the framing effect; then we briefly summarize the research on behavioral finance carried out in Brazil. Afterwards, it is described the research method applied, the main results and the conclusions.

\section{PROSPECT THEORY}

Kahneman and Tversky (1979) proposed an alternative model to describe the economic behavior that they called Prospect Theory. Using survey questions, they demonstrated there are differences between actual people's behavior and the behavior presumed within expected utility theory. Their studies led to some empirical generalizations, such as: the way the problem is framed can lead to changes of choices; gains are treated differently from losses; when there is the possibility of loss, respondents are more prone to take risks, whereas risks are avoided to ensure a gain even though it may be smaller. Results that are perceived as being certain are preferred to those involving some degree of uncertainty.

Kahneman and Tversky's (1979) focus on gains and losses rather than on a final result in terms of assets. Thaler (1980) extends the concept to the purchase of goods, a decision in which there is no risk but yet change of ownership. According to him, receiving something has less value

1 The audit committee, denominated "Conselho Fiscal” in Portuguese, was established by the Brazilian Corporation's Act (BRASIL, 1976). In contrast to similar committees in the US., the Brazilian audit committee is composed of three to five members with a oneyear term who cannot belong simultaneously to the board of directors. Its composition and attributions are detailed in Chapter XIII, articles 160-165A of Act 6404/76 (Corporation's Act). 
than disposing of the same item. This explains why some people generate differences in values between the act of buying and selling. The author calls this discrepancy between the purchase and sales prices the endowment effect. In his tests, when selling certain goods, people ask for higher values than when buying the same goods. Economic theory states that an item of goods has a single value for either buying or selling and when an item is placed on the market at a price above its cost the purpose is to make a profit.

According to Novemsky and Kahneman (2005), the prospect theory suggests that predisposition to buy or sell an asset depends on the point of reference. If an individual has an asset, its value considers the suffering involved in its disposal, whereas if an individual does not have that asset the value considers the satisfaction of owning it. The values eventually become unequal due to loss aversion. This is one of the key points in prospect theory - the existence of a point of reference that makes losses seem larger than the corresponding gains.

This effect does not occur in conditions of poverty. According to the theory, poverty itself is placed below the point of reference. According to Bertrand, Mullainathan and Shafir (2006), among the poor people, the dynamics of business dealings are different, since their choices happen among losses. The amount spent on the acquisition of an asset represents the loss of another asset that could have been acquired.

Ariely (2008) suggests that loss aversion is part of the human condition, as part of our history that can be told by the description of our possessions. This leads to the emergence of some peculiar behaviors, such as passion for what we have, focusing more on losses than on gains, and assuming that others see a transaction from the same perspective as us. This sense of ownership is not limited to material things. It also applies to points of view and ideas.

Carmon and Ariely (2000) point out some attitudes that can mitigate the aversion to losses, such as buyers placing the focus on the benefits of the object. For sellers, they suggest considering alternative uses of the money obtained from its sale.

\section{FRAMING EFFECTS}

Tversky and Kahneman (1981) used the term "frame decision" to refer to the decision maker's concepts in relation to a choice. The frame decision is influenced by the decision maker's beliefs, habits and characteristics as well as by the framing of the problem. Sometimes, one can frame the same problem in different ways. Different framings in relation to the decision-making process can be compared to different perspectives of a landscape. For example, the height of two mountains may appear different according to the location of the observer, but this does not change the actual height of the mountains.

Likewise, in decision models that involve rational choice the decision to choose among the alternatives presented should not change because of changes in the presentation of those alternatives. The authors showed that, due to imperfections in human perception, changes in perspective alter the relative value of the alternatives presented and interfere in decision making.

A classic example of the framing effect is the "Asian disease problem":

\footnotetext{
"Imagine that the U.S. is preparing for the outbreak of an unusual Asian disease, which is expected to kill 600 people. Two alternative programs to combat the disease have been proposed. Assume that the exact scientific estimates of the consequences of the programs are as follows: If program ' $A$ ' is adopted, 200 people will be saved. If program ' $B$ ' is adopted, there is a one-third probability that 600 people will be saved and a two-thirds probability that no people will be saved." (Kahneman, 2011, p. 368).
} 
152 individuals were interviewed and the results were that $72 \%$ chose alternative ' $A$ ' and $28 \%$ chose alternative ' $B$ '. Most of them opted for alternative ' $A$ ', the one that is certain to save lives.

For a second sample group the options were framed differently

"If program ' $A$ ' is adopted, 400 people will die. If program ' $B$ ' is adopted, there is a onethird probability that nobody will die, and a two-third probability that 600 people will die." (Kahneman, 2011, p. 369).

155 individuals were interviewed and the results were that $22 \%$ chose the new alternative ' $A$ ' and $78 \%$ chose the new alternative ' $B$ '.

In both versions, the outcome is the same: 200 people saved in program ' $A$ ' means 400 people would die. Similarly, 400 dead people in program ' $C$ ' would result in 200 people being saved. The framing effect shows that the same results are perceived differently according to the formulation of the problem.

Kahneman (2011) states that the conclusions in relation to the financial issues are well established and that decision makers tend to prefer to ensure a profit rather than bet on a larger profit. When it comes to ensured losses, the trend is to bet to minimize any loss, as well as prefer to retain a certain result rather than gambling the risk of making further losses. The author reports that the experiment was repeated by Amos Tversky in a group of public health professionals and the same results were found. He concluded that not even medical training serves as a defense against the power of framing.

From the financial aspect, the results of a decision can be framed as gains or losses related to their original form or in terms of results that increase the value of the company's assets. The principle of invariance states that changes in the description of the results should not change the order of preference. However, according to Tversky and Kahneman (1981), this principle is frequently seen to fail both between experts and ordinary people. It even occurs when participants answer both questions within a short period of time. For instance, Thaler (1980) showed the same effect in a debate on passing on the costs of credit card transactions to consumers. Companies have adopted the term "discount" in relation to payment in cash, rather than to "increase" in relation to the use of a credit card.

Yaniv (2011) studied the framing effect in the context of groups. Participants were asked to make financial decisions individually and were then separated into homogeneous and heterogeneous groups, classified according to the decision taken. The groups were asked to answer the same questions as a group. The results revealed that the framing effect increases among the homogeneous groups whereas the heterogeneous groups show no differences in choices, thus nullifying the framing effect.

Kim, Kim and Marshall (2013) studied the framing effect in situations involving multiple attributes and multiple choices. The results showed the framing effect influences the evaluation of alternatives and that influence is more pronounced when the positive aspects of the attributes are highlighted.

\section{BEHAVIORAL FINANCE IN BRAZIL}

In Brazil, with few exceptions, studies related to behavioral finance have focused on the capital market and investor reactions. Costa Jr. (1994) examined overreaction in the Brazilian financial market, using two theoretical portfolios, one defined as 'losers', composed of the worst 
performing stocks from the previous month, and the other one as 'winners', comprised of the best performing stocks from the previous month. The results reveal that the overreaction effect is greater than that observed in the North American market. Kimura (2003) conducted a similar study using asset prices from 1994 to 2001 . The results are not statistically significant, suggesting that behavioral aspects have little influence on the Brazilian stock market.

Silva and Yu (2009) studied the relationship between personal characteristics and sense of control. They concluded that there is a relationship between age and sense of control. Both the younger people and the older people show lower levels of sense of control compared to the young adults. Another result related education to health. On average, people who reach old age and retain good level of education and health have higher levels of control.

An exaggerated reaction to recent events may interfere with the behavior of markets. Investors tend to give excessive importance to the most recent information, and so are likely to be surprised in the future, thus leading the returns from the portfolio to revert to the market average. Franco (2002) conducted a study on this subject and found that the results in the Brazilian capital markets are similar to those reported in other countries, showing excessive optimism in the forecasts.

Kimura, Basso and Krauter (2006) reproduced the seminal studies of Tversky and Kahneman (1981) in Brazil. The results showed the same biases found in the original studies, which seem to suggest that the behavioral aspects in decision making suffer little influence from cultural aspects.

The most documented biases according to Yoshinaga, Oliveira, Silveira and Barros (2008) are optimism and overconfidence. Studies of these aspects have resulted in formulations that can be used to explain some financial phenomena. According to the authors, there is still a great deal of research to be done in relation to the biases catalogued in the literature.

Santos and Barros (2011) investigated the presence of heuristics and biases. The results showed that investment and finance decisions are influenced by gender, income, age and education of the respondents. The majority of men have a more aggressive profile, with a greater propensity to take financial risks than most women. The results are similar to those of Smith et al (2009), although the studies were conducted among different groups.

The affective state may interfere with the endowment effect, as shown by Cavazotte, Dias Filho and Vilas Boas (2009), who found empirical evidence that negative emotional states inhibit the endowment effect.

Martits and Eid Junior (2009) investigated loss aversion by comparing the decisions of individual investors with those made by pension funds in Brazil. They concluded that individual investors are more sensitive to risks and pessimistic scenarios, and argue that the traditional utility function does not represent the behavior of those investors. By contrast, pension fund managers are less prone to reject negative scenarios as long as there is the possibility of recovery in the long term.

\section{RESEARCH METHOD}

A database was manually compiled including the names and addresses of executive officers and board members of Brazilian companies listed, based on the records available on the website of the São Paulo stock exchange (BM\&FBovespa) and filings with the Brazilian Securities and Exchange Commission (CVM). At the time of data collection, such files contained 1915 companies. However, only 616 were deemed "operational" according to CVM. From this grand 
total, gross responses were obtained from 229 companies from 31 different sectors, representing $37.18 \%$ of the total. It is believed that such response rate is very reasonable for a field study.

Among those 616 companies, 159 had missing information in their CVM or BM\&FBovespa filings. These problems reduced the number of companies available to be searched to 458 . After eliminating double-counting (people who figured in more than one company), 1840 executives, 820 board members and 417 audit committee members were left.

Those people were contacted by telephone and were asked to answer a questionnaire on financial policies and risk management. All the respondents were identified according to their role and the company they worked for. An overall response rate of over $10 \%$ (315 responses) was reached. From these, 278 valid responses (people who agreed to answer the two behavioral questions) were obtained from 204 companies. Table 1 summarizes the final sampling according to the role of each respondent.

Table 3 - Analysis of the parameters

\begin{tabular}{|c|c|c|c|c|c|}
\hline & Population & Respondents & Valid Responses & $\begin{array}{c}\text { Net Return } \\
\text { Rate }\end{array}$ & $\begin{array}{c}\text { Final Sample } \\
\text { Composition }\end{array}$ \\
\hline Companies & 616 & 229 & 204 & $33.12 \%$ & \\
\hline Executives & 1840 & 141 & 125 & $6.8 \%$ & $44.9 \%$ \\
\hline $\begin{array}{c}\text { Board Members } \\
\text { Audit Committee } \\
\text { Members }\end{array}$ & 820 & 125 & 109 & $13.30 \%$ & $39.2 \%$ \\
\hline TOTAL & 3077 & 315 & 278 & $9.04 \%$ & $100 \%$ \\
\hline
\end{tabular}

Source: elaborated by the authors

Then, a structured telephone interview was conducted or, upon request by the respondent, the questionnaire was sent by e-mail to be responded in writing ${ }^{2}$. The instrument contained 45 questions about the roles of executives and board members, which the respondents answered using a five-point Likert scale of 1 to 5 , with 1 being "strongly disagree" and 5 "strongly agree". The questions were formulated in a way to avoid the socially acceptable response bias ${ }^{3}$. Moreover, previous versions of the questionnaire were submitted to a panel of 3 experts in finance in

2 Albeit only 3 responses were obtained by this method.

3 The full version of our questionnaire is omitted for the sake of concision, but it is available to the interested reader upon request to the authors. 
order to validate its content. Then, the questionnaire was administered to two classes of MBA students (pre-test) in order to further improve it and check for any misunderstanding in the formulations of the questions. The average time to answer the whole questionnaire by phone interview was only 15 minutes.

Towards the end of the questionnaire, two questions related to behavioral finance (Questions I and II below) were included. Exhibit 1 presents these questions. As it can be seen, the final result of both questions would be an $8 \%$ loss or reduction in profit.

Exhibit 1 - Questions about behavioral finance

Below we will ask some questions about your opinion regarding specific risk management operations:

Question I - A company might make a loss of $8 \%$ on a given transaction. How much of the value of transaction would you invest to avoid this loss?

$0 \% \square 1 \%$ a $3 \% \square 3 \%$ a $5 \% \quad \square 5 \%$ a $7 \% \square 8 \%$ or more

Question II - In a commercial transaction, a company made a profit of $10 \%$. If there is a change in the value of the currency, that profit might fall to $2 \%$. How much of the value of transaction would you invest to ensure the original profit?

$\square 0 \% \quad \square 1 \%$ a 3\% $\square 3 \%$ a $5 \% \quad \square 5 \%$ a $7 \% \quad \square 8 \%$ or more

Source: elaborated by the authors

The questions were deliberately placed in sequence, because according to Kahneman and Tversky (1984) violation of the principle of invariance and the emergence of the framing effect occur even when participants answer the questions within a short period of time. Unlike the seminal tests in which the questions were prepared differently and applied to different groups, in this study they were applied to the same group and one after another. This formulation might facilitate the identification of similarity in the decisions and, therefore, lead to little variation in the responses.

\section{RESULTS}

It was obtained a total of 278 responses. From those, 125 came from executives, 109 from Board of Directors members and 44 from Audit Committee members. The number of responses are considerably larger than the original test where the authors obtained 152 responses to the first formulation and 155 to the second one. Table 2 shows the results.

QUESTION I - A company might make a loss of $8 \%$ on a given transaction. How much of the value of transaction would you invest to avoid this loss?

Table 2-Question I: Frequency of responses

\begin{tabular}{|c|c|c|}
\hline Interval & Number of Responses & Percentage \\
\hline $0 \%$ & 19 & $6.83 \%$ \\
\hline $1 \%$ a 3\% & 81 & $29.14 \%$ \\
\hline
\end{tabular}




\begin{tabular}{|c|c|c|}
\hline $3 \%$ a $5 \%$ & 64 & $23.02 \%$ \\
\hline $5 \%$ a $7 \%$ & 33 & $11.87 \%$ \\
\hline $8 \%$ or more & 81 & $29.14 \%$ \\
\hline Total & 278 & $100 \%$ \\
\hline
\end{tabular}

Source: elaborated by the authors

According to utility theory, an investment of up to $7 \%$ would be advantageous for the company because it would prevent the loss of $8 \%$ and would leave a surplus of at least $1 \%$. As it can be seen from Table 2, 29.14\% of the respondents would invest $8 \%$ (which represents the value of the loss) or more. This decision is clearly irrelevant or even value destroying, because the net result would be equivalent to or greater than the expected loss. Given that $6.83 \%$ of the respondents would not invest anything, which means they would accept the loss, and $29.14 \%$ of the respondents would invest the expected value of the loss or more, 35.97\% (more than one third) of respondents make a decision that would not add value to the company.

When segregating the data according to the position held by the respondents, it is seen that board members are more averse to the risk of loss. According to Table 3, 30.28\% of the board members would invest the same percentage or more to avoid a loss. The AC members are more divided: $29.55 \%$ would invest between $1 \%$ and $3 \%$, and $29.55 \%$ would invest $8 \%$ or more. Executives seem to be less risk averse, with $31.20 \%$ opting for the range from $1 \%$ to $3 \%$ and $28 \%$ opting to invest $8 \%$ or more.

Table 3-Question I: Responses according to the position held

\begin{tabular}{|c|c|c|c|c|c|c|}
\hline & \multicolumn{2}{|c|}{ Board of Directors } & \multicolumn{2}{c|}{ Audit Committee } & \multicolumn{2}{c|}{ Executives } \\
\hline Interval & Number & Percentage & Number & Percentage & Number & Percentage \\
\hline $0 \%$ & 9 & $8.26 \%$ & 1 & $2.27 \%$ & 9 & $7.20 \%$ \\
\hline $1 \%$ to $3 \%$ & 29 & $26.61 \%$ & 13 & $29.55 \%$ & 39 & $31.20 \%$ \\
\hline $3 \%$ to $5 \%$ & 26 & $23.85 \%$ & 11 & $25.00 \%$ & 27 & $21.60 \%$ \\
\hline $5 \%$ to $7 \%$ & 12 & $11.01 \%$ & 6 & $13.64 \%$ & 15 & $12.00 \%$ \\
\hline $8 \%$ or more & 33 & $30.28 \%$ & 13 & $29.55 \%$ & 35 & $28.00 \%$ \\
\hline Total & 109 & $100 \%$ & 44 & $100 \%$ & 125 & $100 \%$ \\
\hline
\end{tabular}

Source: elaborated by the authors

The data in Table 3 show that the directors behave as foreseen in the prospect theory, where the values are assigned to the losses and not to the final result, because most of them choose to invest a percentage equal to or higher than the loss, a decision that will not change the final results. This effect is smaller in executives since most of them opted for an investment of $1 \%$ to $3 \%$, which would generate a positive result for the company.

According to Table $4,38.54 \%$ of the board members, $31.82 \%$ of the AC members and $35.2 \%$ of the executives would have reduced the shareholders' wealth, by investing nothing $(0 \%)$, or by investing the same percentage as the probable loss ( $8 \%$ or more). 
Table 4 - Question I: Responses according to the loss level

\begin{tabular}{|c|c|c|c|c|c|c|c|c|}
\hline \multirow[b]{2}{*}{ Interval } & \multicolumn{2}{|c|}{ Board of Directors } & \multicolumn{2}{|c|}{ Audit Committee } & \multicolumn{2}{|c|}{ Executives } & \multicolumn{2}{|c|}{ Total } \\
\hline & Number & Percentage & Number & Percentage & Number & Percentage & Number & $\begin{array}{l}\text { Percent- } \\
\text { age }\end{array}$ \\
\hline $0 \%$ & 9 & $8.26 \%$ & 1 & $2.27 \%$ & 9 & $7.20 \%$ & 19 & 6.83 \\
\hline $8 \%$ or more & 33 & $30.28 \%$ & 13 & $29.55 \%$ & 35 & $28.0 \%$ & 81 & 29.13 \\
\hline Total & 42 & 38.54 & 14 & 31.82 & 44 & $35.2 \%$ & 100 & 35.96 \\
\hline
\end{tabular}

Source: elaborated by the authors

The prospect theory recommends that the decisions consider losses at a higher level than the final result. Table shows that, because a total of $35.2 \%$ of respondents would make decisions that would result in a negative result for the company.

QUESTION II - In a commercial transaction, a company made a profit of $10 \%$. If there is a change in the value of the currency, that profit might fall to $2 \%$. How much of the value of transaction would you invest to ensure the original profit?

Table 5-Question II: Frequency of responses

\begin{tabular}{|c|c|c|}
\hline Interval & Number of Responses & Percentage \\
\hline $0 \%$ & 17 & $6.12 \%$ \\
\hline $1 \%$ to $3 \%$ & 69 & $24.82 \%$ \\
\hline $3 \%$ to $5 \%$ & 69 & $24.82 \%$ \\
\hline $5 \%$ to $7 \%$ & 56 & $20.14 \%$ \\
\hline $8 \%$ or more & 67 & $24.10 \%$ \\
\hline Total & 278 & $100 \%$ \\
\hline
\end{tabular}

Source: elaborated by the authors

Table 5 displays the results. When it comes to reducing profits rather than losses, there are changes in the responses. Even if the final result is the same (a loss of $8 \%$ or a reduction in the profit from $10 \%$ to $2 \%$ ), there is a five-percentage-point reduction in the maximum investment amount and an increase of nine percentage points in the interval from $5 \%$ to $7 \%$, which would be according to the expected utility. Therefore, we find evidence supporting the presence of the framing effect in the responses, even though it may be mitigated by the fact that the relevant questions are asked in sequence. The results in Table 5 show that the vast majority, approximately $70 \%$, would make investments within the range that would produce gains for the company, that is, they would invest from $1 \%$ to $7 \%$.

Table 6 presents the results according to the position held. Board members changed their responses the most. While $22.02 \%$ of the board members would invest the maximum percentage of $8 \%$ or more to avoid a "reduction in profit", $30.28 \%$ would invest the same amount to avoid a "loss". The AC members increase their loss aversion when it comes to "profit reduction": while $36.36 \%$ would invest $8 \%$ or more, only $29.25 \%$ would invest the same amount to avoid a loss in Question I. Once again, the executives are the least averse, with only $21.60 \%$ opting for the range of $8 \%$ or more. 
Table 6-Question II: Responses according to the position held

\begin{tabular}{|c|c|c|c|c|c|c|}
\hline & \multicolumn{2}{|c|}{ Board of Directors } & \multicolumn{2}{c|}{ Audit Committee } & \multicolumn{2}{c|}{ Executives } \\
\hline Interval & Number & Percentage & Number & Percentage & Number & Percentage \\
\hline $0 \%$ & 10 & $9.17 \%$ & 1 & $2.27 \%$ & 6 & $4.80 \%$ \\
\hline $1 \%$ to $3 \%$ & 27 & $24.77 \%$ & 11 & $25.00 \%$ & 31 & $24.80 \%$ \\
\hline $3 \%$ to $5 \%$ & 24 & $22.02 \%$ & 8 & $18.18 \%$ & 37 & $29.60 \%$ \\
\hline $5 \%$ to $7 \%$ & 24 & $22.02 \%$ & 8 & $18.18 \%$ & 24 & $19.20 \%$ \\
\hline $8 \%$ or more & 24 & $22.02 \%$ & 16 & $36.36 \%$ & 27 & $21.60 \%$ \\
\hline Total & 109 & & 44 & & 125 & \\
\hline
\end{tabular}

Source: elaborated by the authors

According to the results in Table 6, the Audit Committee showed more clearly the endowment effect. According to Thaler (1980), the largest number of respondents stated invest a percentage equal to the greater reduction of profit. This loss aversion (having a 10\% profit and reducing to $2 \%$ ) makes the choice befall the maximum investment to stop that from happening, even if it does not change the final result, while in the groups of executives and directors the largest number of responses was for the intermediate range and that generate positive results.

Table 7 consolidates the results. $38.63 \%(36.36 \%+2.27 \%)$ of the total respondents of AC members decided for a reduction in the profits. $31.19 \%$ of the board members would make a decision that would result in a loss for the company when the "profit reduction" approach was used, against 38.54\% when making a "loss" approach was used in Question I. The largest reduction occurred among the executives interviewed in this question, as $26.40 \%$ opted for an investment that reduces the profit from the transaction, while in Question I (where the term "loss" was present), $35.2 \%$ of the respondents chose those options. The reduction was the greatest in the range from " $8 \%$ or more": whereas in the previous question $28 \%$ chose this alternative, in this question the number of respondents was $21.60 \%, 6.40$ percentage points lower.

Table 7 - Question II: Responses according to the profit reduction level

\begin{tabular}{|c|c|c|c|c|c|c|c|c|}
\hline \multirow[b]{2}{*}{ Interval } & \multicolumn{2}{|c|}{ Board of Directors } & \multicolumn{2}{|c|}{ Audit Committee } & \multicolumn{2}{|c|}{ Executives } & \multicolumn{2}{|c|}{ Total } \\
\hline & Number & Percentage & Number & Percentage & Number & Percentage & Number & $\begin{array}{l}\text { Percent- } \\
\text { age }\end{array}$ \\
\hline $0 \%$ & 10 & $9.17 \%$ & 1 & $2.27 \%$ & 6 & $4.80 \%$ & 17 & $6.11 \%$ \\
\hline $8 \%$ or more & 24 & $22.02 \%$ & 16 & $36.36 \%$ & 27 & $21.60 \%$ & 67 & $24.10 \%$ \\
\hline Total & 34 & $31.19 \%$ & 17 & 38.63 & 33 & $26.40 \%$ & 84 & $30.21 \%$ \\
\hline
\end{tabular}

Source: elaborated by the authors

Table 8 shows the changes in the responses of the board members. The range is from -7.35 percentage points, indicating that the framing of the questions changed the response.

Table 8 - Changes in the responses of Board Members according to the framing of the question

\begin{tabular}{|c|c|c|c|c|c|}
\hline \multicolumn{4}{|c|}{ Board of Directors } \\
\hline & \multicolumn{2}{|c|}{ Loss } & \multicolumn{2}{|c|}{ Reduction in Profit } & \\
\hline Interval & Number & Percentage & Number & Percentage & Variation \\
\hline
\end{tabular}




\begin{tabular}{|c|c|c|c|c|c|}
\hline $0 \%$ & 9 & $8.26 \%$ & 10 & $9.17 \%$ & 0.91 \\
\hline $8 \%$ or more & 33 & $30.28 \%$ & 24 & $22.02 \%$ & -8.26 \\
\hline Total & 42 & 38.54 & 34 & $31.19 \%$ & -7.35 \\
\hline
\end{tabular}

Source: elaborated by the authors

The responses in Table 9 show that the Audit Committee members reacted differently from the board members. The "profit reduction" effect led them to increase the responses in $8 \%$ or more.

Table 9 - Changes in the responses of Audit Committee Members according to the framing of the question

\begin{tabular}{|c|c|c|c|c|c|}
\hline \multicolumn{7}{|c|}{ Audit Committee } \\
\hline & \multicolumn{2}{|c|}{ Loss } & \multicolumn{2}{c|}{ Reduction in Profit } & \\
\hline Interval & Number & Percentage & Number & Percentage & Variation \\
\hline $0 \%$ & 1 & $2.27 \%$ & 1 & $2.27 \%$ & 0 \\
\hline $8 \%$ or more & 13 & $29.55 \%$ & 16 & $36.36 \%$ & +6.81 \\
\hline Total & 14 & 31.82 & 17 & 38.63 & +6.81 \\
\hline
\end{tabular}

Source: elaborated by the authors

The responses of executives in Table 10 show changes in line with those of the board members. The change in the form of the question led them to reduce the spending to avoid a loss by 8.8 percentage points.

Table 10 - Changes in the responses of Executive Officers according to the framing of the question

\begin{tabular}{|c|c|c|c|c|c|}
\hline \multicolumn{5}{|c|}{ Loss } & \multicolumn{2}{c|}{ Reduction in Profit } & \\
\hline Interval & Number & Percentage & Number & Percentage & Variation \\
\hline $0 \%$ & 9 & $7.20 \%$ & 6 & $4.80 \%$ & -2.40 \\
\hline $8 \%$ or more & 35 & $28.0 \%$ & 27 & $21.60 \%$ & -6.40 \\
\hline Total & 44 & $35.2 \%$ & 33 & $26.40 \%$ & -8.80 \\
\hline
\end{tabular}

Source: elaborated by the authors

The data in Tables 8, 9 and 10 show the consolidated data and the changes in the responses that do not generate positive results. Based on them, it is possible to see that the changes of the Board of Directors and of the Executives Officers follow the same trend, both being more sensitive to "loss" than to "reduction in profit." The Audit Committee changed their decision in the opposite direction, being more sensitive to "reduction in profit". As pointed out by Thaller (1980) the endowment effect is not universal, and the results show that it appears more strongly on the Audit Committee in relation to the other respondents. 


\section{CONCLUSIONS}

The interest in the field of behavioral finance has grown in recent years due to the difficulty scholars face in explaining some financial decisions observed in practice. According to Kahneman and Tversky (1984) questions that are formulated, or framed, differently can lead to different responses even among experts. In order to test this proposition, the present study investigates the framing effect among board members and executives of publicly traded companies, a group chosen considering the impact of the decisions they make and their consequences.

In our experiment, one of the questions addresses the possibility of making a loss of $8 \%$. Another question refers to the possibility of a reduction in profit from $10 \%$ to only $2 \%$. In both cases, the company would experience a net reduction in value equal to $8 \%$. The respondents should decide how much to invest in order to avoid the loss or the reduction in profit, whose options ranged from $0 \%$ to $8 \%$ or more.

The results were analyzed under several aspects. The first one of them was whether the respondents had changed the answer to the question being formulated in another way. Another analysis found that the changes occurred in the same way, if all positions changed responses by increasing or decreasing the investments in accordance with the wording of the question or there was some divergence. Another aspect analyzed was the behavior of the respondents according to the position held and whether they were more sensitive to some of the issues.

The overall results show that the framing effect is revealed in all respondents and the decisions were different according to the terms used in the questions. The changes do not have the same bias, but may be in the opposite direction according to the position held.

When the question used the term "loss", most of the directors and the Audit Committee opted for alternatives that resulted in negative results for the company. When the question involved "reduction in profit", part of the board of directors changed their response and opted for alternatives that generated positive results. The Audit Committee changed their answer, but in another way, the number of those who opted for investments that resulted in negative results increased, which means that the pain of loss as stipulated in the prospect theory, which, in this case, means having a "reduction in profit" is more important to the Audit Committee than to the board of directors. These results may suggest different attitudes according to the position held and the responsibility upon the organizations. May the Audit Committee be evaluating other aspects related to the loss and that would not be considered by others? Or is the word "loss" less important in making a decision since it can generate tax benefits?

The executives are more sensitive to avoid the "loss", and most of them opted for options that generated negative results, while in the question about "reduction in profit" the percentage of those who made this option had a significant drop.

The results suggest that the framing effect occurs differently among AC members and the other respondents. ${ }^{4}$ With respect to the loss, $30.28 \%$ of the board members opt to spend $8 \%$ or more, while only $22.02 \%$ would do the same to avoid reducing a profit, a drop of 8.26 percentage points. Executives change their response from $28 \%$ (loss) to $21.6 \%$ (reduction in profit), a drop of 6.4 percentage points. In contrast, AC members increased their responses from $29.55 \%$ in the case of a loss to $36.36 \%$ in the case of a reduction in profit - an increase of 6.81 percentage points. Future studies could explore these issues as well as the influence of the position held within the organization, professional background and other personal aspects in decision-making, as well as the relations among the various agents in organizations. By broadening the research, we could explore the assessments and decisions regarding new projects and other 
aspects of investment decisions in the organizational environment.

This research contributes towards the field of behavioral finance by demonstrating how the framing effect manifests even among a group of experts. Board members and executive officers are at first qualified, well prepared, and hold positions in which they are frequently called upon to decide, advise, or evaluate critical decisions. The main findings of this study suggest the presence of the framing effect even among these qualified professionals.

\section{REFERENCES}

ARIELY, D. Predictably Irrational: The Hidden Forces That Shape Our Decisions, 1sted. New York: Harper Collins, 2008. 280 p.

BERLE, A. A.; MEANS, G. C. The Modern Corporation and Private Property, 1st ed. New York: Macmillan, 1932. 414p.

BERTRAND, M.; MULLAINATHAN, S.; SHAFIR, E. "Behavioral economics and marketing in aid of decision-making among the poor". Journal of Public Policy \& Marketing, v. 25, n. 1, p. 8-23, 2006.

BRASIL, Lei n. ${ }^{\circ}$ 6.404, de 15 de dezembro de 1976. Dispõe sobre as Sociedades por Ações. Diário Oficial da União, Brasília, DF, 15 dez. 1976. Seção 1 (suplemento).

CARMON, Z.; ARIELY, D. "Focusing on the forgone: how value can appear so different to buyers and sellers". Journal of Consumer Research, v. 27, p. 360-370, 2000.

CAVAZOTTE, F.; DIAS FILHO, P.; VILAS BOAS, O. "A influência das emoções sobre o efeito dotação". Revista Brasileira de Finanças, v. 7, n. 2,p. 196-213, 2009.

COPELAND, T. E.; WESTON, F. J.; SHASTRI, K. Financial Theory and Corporate Policy, 4th ed. Pearson Education, 2005. 1024 p.

COSTA Jr. N. C. A. "Overreaction in the Brazilian stock market". Journal of Banking and Finance, n. 18 p. 633-642, 1994.

FRANCO, D. "Projeções de lucros sistematicamente exageradas: um estudo para o Brasil”. Revista Brasileira de Economia, n. 56, v. 4, p. 591-603, 2002.

GARVEY, G. T.; SWAN, P. L. "The economics of corporate governance: beyond the Marshallian firm". Journal of Corporate Finance, n. 1, p. 139-174, 1994.

KAHNEMAN, D. Thinking, Fast and Slow, 1sted. New York: Farrar, Strausand Giroux, 2011. 499 p. KAHNEMAN, D.; TVERSKY, A. “Choice, values and frames”. American Psychologist, v. 39, n. 4 p. 341-350, 1984.

\footnotetext{
4 Of course, our research method does not allow us to rule out a number of alternative explanations for our findings besides the framing effect. This is a limitation of our results, so any further conclusions must be taken with caution. We are thankful to an anonymous referee for pointing this out.
} 
KAHNEMAN, D.; TVERSKY, A. “Prospect Theory: An Analysis of Decision under Risk, Econometrica, vol. 47, Issue 2, p. 263-292, 1979

$\mathrm{KIM}$, J.; KIM, J.; MARSHAL, R. "Search for the underlying mechanism of framing effects in multialternative and multi-attribute decision situations". Journal of Business Research, 2013, p. 1-8, In Press: http://dx. doi. org/10. 1016/j. jbusres. 2012. 12. 024.

KIMURA, H.; BASSO, L. F. C.; KRAUTER, E. “Paradoxos em finanças: teoria moderna versus finanças comportamentais". Revista de Administração de Empresas RAE, v. 46, n. 1, p. 41-58, 2006.

KIMURA, H. "Aspectos Comportamentais associados às reações do mercado de capitais". Revista de Administração de Empresas RAE-eletrônica, v. 2, n. 1, p. 1-14, 2003, disponível em: http:// www. scielo. br/pdf/raeel/v2n1/v2n1a06. pdf. Acessado em 10. 01. 2013.

LA PORTA, Rafael; LOPES-DE-SILANES, Florencio; SHLEIFER, ANDREI; Visny W. Law And Finance. The Journal of Political Economy, vol 106, Issue 6, p. 1113-1155, 1998

MARTITS, L. A.; EID JUNIOR, W. "Aversão a Perdas: Comparação de decisões de investimento entre investidores individuais e fundos de pensão no Brasil". Revista Brasileira de Finanças, v. 7, n. 4, p. 429-457, 2009.

NOVEMSKY, N.; KAHNEMAN, D. “The boundaries of loss aversion”. Journal of Marketing Research. v. XLII, p. 119-128, 2005.

PENG, M. W.; SAUERWALD, S. "Corporate Governance and Principal-Principal Conflicts", in: WRIGHT, M.; SIEGEL, D. S.; KEASEY, K.; FILATOTCHEV, I. (eds.). The Oxford Handbook of Corporate Governance, Oxford, UK: Oxford University Press, p. 658-672, 2013.

ROSS, S. A.; WESTERFIELD, R. W.; JAFFE, J. F. Corporate Finance, 9th ed. New York: McGraw-Hill Irwin, 2010. 978 p.

SANTOS, J. O. dos; BARROS, C. A. S. "O que determina a tomada de decisão financeira: razão ou emoção?" Revista Brasileira de Gestão de Negócios, v. 13, n. 38, p. 7-20, 2011.

SILVA, W. M.; YU, A. S. O. "Análise empírica do senso de controle: buscando entender o excesso de confiança”. Revista de Administração Contemporânea RAC, v. 13, n. 2, p. 247-271, 2009.

THALER, R. "Toward a positive theory of consumer choice". Journal of Economic Behavior and Organization, n. 1, p. 39-60, 1980.

TVERSKY, A.; KAHNEMAN, D. "Judgment under uncertainty: heuristics and biases". Science, v. 185, n. 4157, p. 1124-1131, 1974.

TVERSKY, A.; KAHNEMAN, D. "The framing of decisions and the psychology of choice". Science v. 211, p. 453-458, 1981.

YANIV, I. "Group diversity and decision quality: amplification and attenuation of the framing effect". International Journal of Forecasting, n. 27, p. 41-49, 2011.

YOSHINAGA, C. E.; OLIVEIRA, R. de F.; SILVEIRA, A. Di M.; BARROS, L. A. B. de C. "Finanças comportamentais: uma introdução". Revista de Gestão da USP, v. 15, n. 3, p. 25-35, 2008. 